\title{
Article
}

\section{The Influence of Opinion Leaders' eWOM on Online Consumer Decisions: A Study on Social Influence}

\author{
Sandra Tobon * and Jesús García-Madariaga \\ Faculty of Economics and Business, Complutense University of Madrid, 28223 Madrid, Spain; jesgarci@ucm.es \\ * Correspondence: stobon@ucm.es
}

Citation: Tobon, S.; García-Madariaga, J. The Influence of Opinion Leaders' eWOM on Online Consumer Decisions: A Study on Social Influence. J. Theor. Appl. Electron. Commer. Res. 2021, 16, 748-767. https://doi.org/10.3390/jtaer 16040043

Received: 30 November 2020 Accepted: 12 January 2021 Published: 19 January 2021

Publisher's Note: MDPI stays neutral with regard to jurisdictional claims in published maps and institutional affiliations.

Copyright: (C) 2021 by the authors. Licensee MDPI, Basel, Switzerland. This article is an open access article distributed under the terms and conditions of the Creative Commons Attribution (CC BY) license (https:// creativecommons.org/licenses/by/ $4.0 /)$.

\begin{abstract}
Opinion leaders and eWOM are becoming two of the most effective ways to launch a brand on social media by creating viral marketing. However, how much influence does an opinion leader's eWOM (OL eWOM) have on consumer purchasing decisions? This research looks at the role of OL eWOM as well as the effect of its valence and product type on the decision to buy or not buy from a realistic experimental online store design. In total, 300 undergraduate students were randomly assigned to one of five scenarios in a $2^{2}$ experimental arrangement. Results show that OL eWOM influences consumer online decisions when purchasing experience-type goods and the valence of eWOM is positive. However, if we compare the OL eWOM with a control group, then OL eWOM does not have a significant influence. This research provides novel empirical evidence for the limited influence of OL in modeling shopping behaviors in e-commerce contexts.
\end{abstract}

Keywords: opinion leader' eWOM; online consumer decisions; product type; $\mathrm{eWOM}^{\prime}$ valence; personal influence

\section{Introduction}

An opinion leader (OL) is a consumer who provides information that influences the consumption decisions of others by obtaining essential information through research and shaping their own opinion before making it public [1]. Its importance in product promotion [2] and product introduction [3] has been exploited by practitioners and studied by researchers in traditional marketing strategies. However, they have received less attention in terms of their effect on online consumer decisions.

According to the Global Web Index [4], almost 97\% of online adult users have at least one social media account, 91\% are Facebook users, and people spend an average of $2 \mathrm{~h}$ and $43 \mathrm{~min}$ a day on social networks and messaging. A total of $87 \%$ of users engage in social media to keep up with their friends and read the news to fill the time. Likewise, $87 \%$ of consumers acknowledge reading product recommendations on the web before making online purchases and $93 \%$ say they follow celebrities, artists, or athletes on social networks. According to Bao and Shan [1], the two main sources of information that consumers review before making consumption decisions are OL and OL's eWOM comments on their social media accounts.

In the digital consumer era, people are connected through the web and linked to social networks where they follow artists, politicians, or celebrities whom they admire and trust. In this context, any comment or recommendation posted by such a personality has a wide impact on his/her followers. This form of eWOM (OL eWOM) becomes an indispensable source of information that needs to be analyzed in terms of its actual influence on purchase decisions. It is even more important than evaluating the virality of the information in user-generated content platforms.

Social media users tend to follow their OL and seek advice on their consumer decisions. So, celebrities' followers know what products and services a celebrity is buying or using [5]. These types of public figures become of great interest to marketers trying to use the 
platform to promote their products [6]. For example, Cristiano Ronaldo, who has more than 122 million followers on Facebook [7], promotes banks, video games, sports clothes, and smartphones. However, how effective are these marketing strategies? How much do they influence consumer behavior?

As stated by Katz and Lazarsfeld [2], an OL is a person with the position and ability to influence the consumption decisions of others. Katz [8] showed that in the traditional commercial model, an OL is a person who has contact, due to his/her professional activity, with a large number of people with whom he/she shares his/her opinions and preferences. According to this model, these characters are key to the dissemination of information about new products or services. OL obtains key information through research and shapes his/her own opinion before making it public [1].

As maintained by Katz [8], an opinion leader is characterized by personal predisposition ("Who one is"), competence ("What one knows") and, social connections ("Whom one knows").

However, with the massification of social networks, the role of these personalities has been changing: their number of followers has multiplied exponentially, and therefore, they can easily reach a large number of people but do they retain the ability to massively change purchasing attitudes and behaviors?

On the other hand, there is literature regarding the eWOM's influence on consumer intentions, including specific characteristics of the eWOM, such as valence [9], the page where it is posted [10], the source's credibility [11], or personal characteristics [12]. The aforementioned have a differential effect on online consumer decisions [13]. However, it has not been proven that this kind of communication has any effect when an OL sends it. Given that it can be considered a source of corporate information since most of the time celebrities are promoting a brand for payment [14], it is necessary to analyze whether this source of information influences the consumer purchase decisions.

There is traditional marketing literature that has studied the influence of OLs on purchasing decisions [3,15], also the endorsement of celebrities [16], and there is relative consensus regarding its effectiveness in building brand loyalty. More recently, and with the widespread use of social networks, literature has emerged that analyzes, through online questionnaires, how much advertising with digital celebrities [17], influencers [18], celebrities [19], among others, influences the consumer purchase intentions, intention to share, eWOM intention, or brand preference of their followers on social networks.

This research analyzes the influence of a product review posted by an OL through a social network (Facebook) on purchasing decisions for a product and a service, using an online experiment. We use the original conception of "opinion leader" [2], which refers to a public figure with social recognition, regardless of his/her profession or how he/she obtained his/her recognition. The study is part of the literature that analyzes OLs social influence on the purchase decisions of its followers. It differs from the literature on "celebrities' endorsement" insofar as, instead of the Influencer appearing in an advertising message using or promoting the brand or product in question $[6,20]$, they comment on their experience or opinion on it. In this sense, we start from the eWOM literature, where the sender is a publicly recognized character who comments on his/her experience as a consumer.

As far as we know, it is the first study that empirically evaluates the effect of an online review posted by an OL on their social network account without any financial compensation from the brands mentioned, which shows the extent of their influence on the final decision to buy or not a product and service.

This research answers the following questions: 'How much is an OL's eWOM influencing consumer purchase decisions in the e-commerce context?' 'Does OL eWOM have the same influence on the purchase of a search good as it does on the purchase of an experience one?' and 'Does the OL eWOM influence vary depending on its positive or negative valence of the recommendation?' 
The objectives of this research are twofold: 1 . Analyze the level of influence of the eWOM generated by an OL in the decisions to buy or not buy an online product or service and 2. Establish the interaction effect of the product type and the valence of the message on the influence of the OL eWOM.

The research results are pioneers in studying the role of OLs' eWOM with an online experiment, analyzing their influence on online purchasing decisions. The results are analyzed and discussed in light of theories on social influence and consumer behavior.

\section{Literature Review and Hypotheses}

The following is a review of the main and most recent literature on OL and valence and the type of product referred to in the eWOM literature. Based on this literature, the hypotheses to be tested empirically in this research are formulated.

For the search and selection of the literature, we have reviewed the Scopus and Web of Science databases, using as keywords the titles of the documents (paper, Journal, and books): "Opinion leader", "Opinion leadership", "Consumer behavior" "marketing" "social influence" "Influencer". The period analyzed was 2015-2020, even though other papers and books from previous years were included when the volume of citations was considered fundamental to address the subject. Articles that dealt with OL from a mathematical perspective (how to identify them), political science, or other areas other than the area of consumer behavior were excluded.

\subsection{Opinion Leadership}

Opinion leadership refers to an individual's ability to informally shape the attitudes, opinions, and overt behavior of others [2,3]. An OL is a person that, due to their competence (knowledge), personal traits, or expertise, can change the attitudes, opinions, or behaviors of their followers [3,21].

According to the traditional concept, personal predispositions characterize an OL"Who one is"—, competence- "What one knows"-, and social connections_- "Whom one knows" [8].

Regarding personal predispositions, Weimann [22] confirmed the "Personality Strength Scale" and showed that people with high personality strength scores tend to become an OL and occupy a central position in the social network. These kinds of people are usually charismatic and see themselves as having the possibility to influence the attitudes and behaviors of others.

Concerning to competence, Loeper, Steiner and Stewart [23] presented evidence that people with more knowledge or ability on a given subject influence the behavior of their followers, even when their opinion is biased. As for social connections, an OL is someone who has contact with lots of people and who can, therefore, interchange information and opinions with them [24].

However, Gnambs and Batinic [12] demonstrated that for an OL to have a real influence on his/her followers, competence or knowledge alone is not enough- They showed that OL must also have specific competencies and independent dominant personality traits such as influencers. The authors emphasized that "with increasing levels of influencer traits, the effect of knowledge on opinion leadership gradually decreases; i.e., objective knowledge is first and foremost important for those who are not influential by disposition" [12]. Therefore, coinciding with Gnambs et al., knowledge is a precondition for OL, but it is not essential [12,25].

Further, brands use social media to promote their products [26]. In this context, where the number of followers or likes determines the influence that a person receives, image, comment, or opinion [27], and where anyone can post their opinion freely publish through different types of eWOM as reviews, recommendations, and likes, anyone can become an OL, even in contexts where they are not an expert [28]. While this strategy has had success in terms of communication [29] when launching a new product, most of the time it focuses solely on generating activity on social networks rather than generating actual sales. 
Recent literature on Opinion Leadership (Table 1) has analyzed the role of messages about brands or products posted by OLs on their social media accounts and has evaluated their influence on attitudes and intentions to buy the referred product. The results allow us to conclude that OL has an influence both on the diffusion of messages and on attitudes towards a brand. However, the empirical study of how much this influence affects the final decision to buy or not the product is a matter of pending investigation.

Table 1. Recent empirical evidence on Opinion Leadership.

\begin{tabular}{|c|c|c|c|c|c|c|}
\hline DV & IV & Context & Methodology & Results & $\begin{array}{c}\text { Social } \\
\text { Influence }\end{array}$ & Cite \\
\hline $\begin{array}{l}\text { Information } \\
\text { diffusion } \\
\text { process }\end{array}$ & $\begin{array}{l}\text { Key Opinion } \\
\text { Leaders } \\
\text { (KOL's) }\end{array}$ & $\begin{array}{l}\text { Sina Weibo' } \\
\text { data users }\end{array}$ & Web scraping & $\begin{array}{l}\text { KOLs play a central role in the } \\
\text { dissemination of information, } \\
\text { especially in its initial stage. }\end{array}$ & Yes & [26] \\
\hline $\begin{array}{c}\text { Potential } \\
\text { opinion leaders }\end{array}$ & $\begin{array}{l}\text { Follower } \\
\text { numbers, } \\
\text { comment tone }\end{array}$ & Weibo & Experiment & $\begin{array}{l}\text { There is no evidence that } \\
\text { neither the number of } \\
\text { followers nor the tone of the } \\
\text { messages contributes to } \\
\text { forming judgments about } \\
\text { potential opinion leaders. }\end{array}$ & No & [30] \\
\hline $\begin{array}{c}\text { Opinion } \\
\text { leaders' eWOM }\end{array}$ & $\mathrm{N} / \mathrm{A}$ & $\begin{array}{l}\text { Blogs about } \\
\text { Spanish food }\end{array}$ & Questionnaire & $\begin{array}{l}\text { The comments posted by } \\
\text { opinion leaders about Spanish } \\
\text { food set a trend in the } \\
\text { behavior of their followers }\end{array}$ & Yes & [31] \\
\hline $\begin{array}{l}\text { Consumer } \\
\text { attitude and } \\
\text { intention to buy }\end{array}$ & $\begin{array}{c}\text { OL persuasive } \\
\text { messages }\end{array}$ & $\begin{array}{l}\text { Instagram } \\
\text { survey }\end{array}$ & Questionnaire & $\begin{array}{l}\text { The messages issued by } \\
\text { opinion leaders have a } \\
\text { positive influence on the } \\
\text { attitudes and purchase } \\
\text { intentions of their followers }\end{array}$ & Yes & [32] \\
\hline Media trust & $\begin{array}{l}\text { Social media } \\
\text { recommenda- } \\
\text { tion }\end{array}$ & Facebook & Experiment & $\begin{array}{l}\text { Product recommendations } \\
\text { increase credibility in the } \\
\text { media and the probability of } \\
\text { following the sender of the } \\
\text { message. This is more forceful } \\
\text { when the person who posts } \\
\text { the message is a real friend of } \\
\text { the follower and presents } \\
\text { himself as an opinion leader. }\end{array}$ & Yes & [27] \\
\hline
\end{tabular}

Therefore, it is legitimate to wonder how much influence do OL eWOMs have on the final decision to buy or not a product or service? Shan [33] analyzed the credibility of self-generated online product reviews versus system-generated online product reviews and found that the most credible source was the self-generated product reviews posted by top reviewers as opposed to layman reviews. However, the literature on the influence of OL on consumer decisions is contradictory. For example, Moldovan et al. [34] showed that OLs have influence but in small groups and strong-ties. Libai et al. [35] stated that, compared with a control group, OLs had not had a significant influence on the value of the company. Katona et al. [36] found that OLs have less influence than other consumer recommendations, and finally, Danniswara et al. [37] provided evidence that eWOM, information quality, and brand preference are relevant dimensions in consumer's purchasing intentions and purchasing decisions. However, they found that celebrity endorsement does not have significant influence on consumer purchasing decisions.

On the other hand, Iyengar et al. [3] found that OLs have more influence as they are heavy users of a specific product. Wang et al. [26] stated that OLs are the most effective source of message dissemination. In the same direction, Weimann [22] showed that compared to no OLs, the OLs spread more brand information and news for followers 
to make decisions. Likewise, Sari et al. [6] found that celebrity endorsed brands, eWOM and trust in the brand are decisive in the women's fashion purchasing decisions.

Based on the above evidence, the first hypothesis was formulated:

Hypothesis 1 (H1). A product with an eWOM posted by an OL is more likely to be purchased.

\subsection{The eWOM' Valence}

Valence is the direction of the eWOM consumer's reviews and can be positive or negative. "Positively framed eWOM highlights the strengths of a product/service and encourages people to adopt a particular product/service, while negatively framed eWOM emphasizes the weaknesses and problems of a product or service and thus discourages people from purchasing it" [13].

There is no consensus about the influence of the eWOM's valence on purchase decisions [38]. Most of the literature analyzes the eWOM valence's influence on purchase intentions, and the results have been inconsistent [39]. Aleti et al. [40] analyzed the influence of communications posted by celebrities, personal trainers, and bloggers on the generation of eWOM on Twitter. They found that celebrity-posted communications are more effective overall on eWOM' generation, but in terms of valence ("emotional style") it had no influence, except in cases where communication was posted by personal trainers and in an "angry outbursts" style.

In the eWOM' literature, there is evidence that negative eWOM (e-NWOM) has a stronger influence on purchase intentions than positive eWOM (e-PWOM), especially with regard to the dissemination of reviews [41].

Hornik et al. [41] showed that people react differently to e-NWOM than they do to e-PWOM: "they are more sensitive to negative information and disseminate it more often to a greater number of recipients, for a longer period and in a more elaborate and assimilated manner" (p. 278). Kim et al. [42] also found that e-NWOM has a negative influence on viewers: when they read e-NWOM, they are more likely to attribute an e-NWOM incident to the company, and as such, are more likely to form negative attitudes toward the company and later show the company less preference.

Doh and Hwang [43] analyzed the relative influence of eNWOM on product evaluation: "a single negative message itself can be harmful to product evaluation. However, one negative message in a 10-message set is not too harmful and can even be beneficial in the eWOM context" (p. 197) since the presence of only positive messages can damage the credibility of the website.

Lastly, Lee et al. [44] found that eNWOM has a negative influence on consumer attitude, regardless of whether the consumer shows a high or low-involvement, regardless of the quality of the message.

On the other hand, Zhang et al. [45] found that e-PWOM is more persuasive than e-NWOM when the consumers evaluate products associated with promotion consumption goals (positivity bias). They perceived e-NWOM to be more persuasive than e-PWOM when the consumer examines a product associated with prevention consumption goals (negativity bias). Jin and Phua [39] reported a negative correlation between the eWOM's valence and the number of followers: consumers are more likely to spread the eWOM of celebrities with a low number of followers when the valence of eWOM is negative. However, they found a positive correlation when the celebrity has a high number of followers because the consumer showed greater intention to spread the celebrity's eWOM when he/she posted reviews with positive valence.

The literature notes the different effects of persuasiveness according to eWOM's valence and product functionality. However, it is necessary to analyze whether the OL eWOM influence is related to the valence of the comments. Following the previously discussed literature, in this research, we hypothesize:

Hypothesis 2 (H2). The influence of OL eWOM on the purchase decision is determined by the valence of the comment. 
In other words, a positive OL eWOM can increase the probability of purchasing a product more than the damage that a negative OL eWOM can have in deterring the purchase of the product.

\subsection{Product Type}

Another variable that influences the effect of OL eWOM on purchasing decisions is the type of product [10]. According to Armstrong and Kotler [46], they could be classified as search products or experience products, respectively [47]. The former (search goods) are those with attributes that can be evaluated before purchase or consumption, while the latter (experience goods) are those that can be accurately evaluated only after the product has been purchased and experienced.

There is convincing evidence that the consumer is more influenced by eWOM when the product that they are buying is an experiential good than when it is a search good. In general, an experiential good represents a higher risk for the consumer due to its intangible nature and the low predictability of the result of the experience with it [10].

However, to the extent that online shopping implies a risky purchase in itself since the consumer does not have the opportunity to interact with the good before to its acquisition, it is necessary to analyze whether the influence of OL eWOMs in the purchase of search or experience products is differential.

Ahmad and Laroche [48] analyzed real consumer reviews on Amazon.com and found that positive reviews were more frequent for product characteristics like functionality, aesthetic, technical aspects, or brands, and that negative reviews were more common for reports of service-related failures (online order, delivery mishandling, or shipping charges). Additionally, the consumers were more inclined to post negatives reviews when the services were unsatisfactory than to post positive reviews when the service was excellent.

In the context of experiential goods, the most-studied services have been tourism and hotel services due to the importance of eWOM in sales [49]. Racherla and Freske [50] found that the most critical eWOM characteristic for experiential goods that the consumer values is eWOM utility, which is moderated by the reviewer's reputation and the number of followers that the reviewer has.

Based on the foregoing, we hypothesize:

Hypothesis 3 (H3). OL eWOM exerts a greater influence on purchasing decisions for experiential goods than on search products.

Although the online purchase of both types of products carries risks for the customer, for the search one, the risk is reduced because the consumer has the opportunity to return them in case of dissatisfaction. This does not happen with experiential goods.

Figure 1 shows a summary of the three hypotheses and possible variable directions.

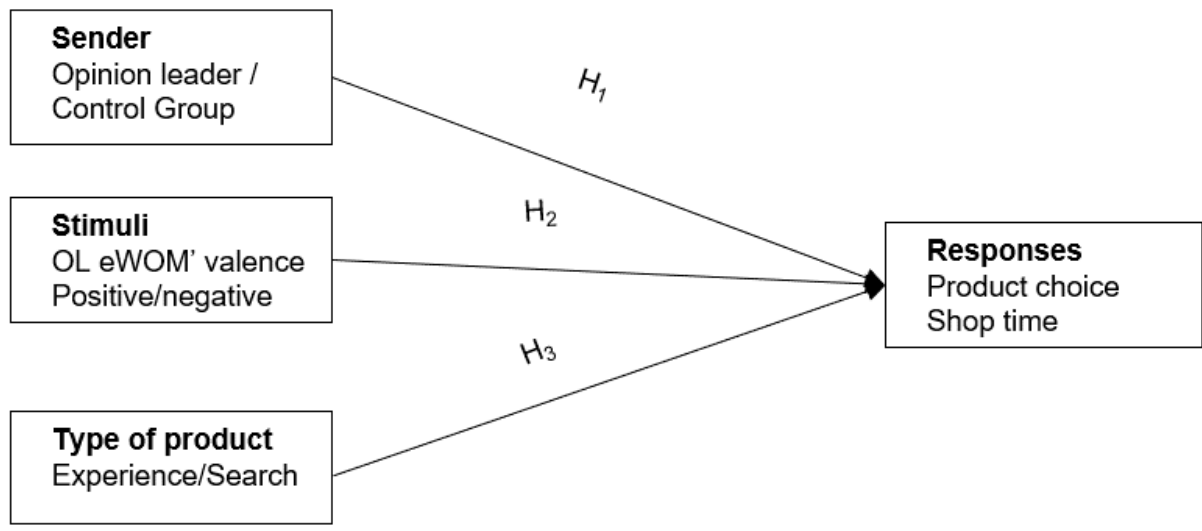

Figure 1. Research model. 


\section{Methodology}

\subsection{Experiment Overview}

The objective of the experiment was to analyze the influence of the comments posted by an OL on their Facebook account in an online shopping context. The procedure had three phases. In the first, the participants registered in the online store. In the second, the participants were randomly assigned to one of the five scenarios of the experiment (see Table 2). At this stage, the participants were exposed to a catalog of smartphones or streaming services where, in addition to the characteristics of the products or services, a comment (positive or negative, depending on the group) attributed to Cristiano Ronaldo that appeared published on his social network. The control group was exposed only to the characteristics of the product or service. From this information, the participants had to decide whether or not to buy the product or service. Finally, in the third stage, the participant was asked to complete a questionnaire on online shopping habits, consumption of social networks, and demographic information.

Table 2. Experimental manipulation: OL eWOM, product type, and eWOM valence.

\begin{tabular}{|c|c|c|c|}
\hline & & \multicolumn{2}{|c|}{ OL eWOM' VALENCE } \\
\hline \multirow{3}{*}{ 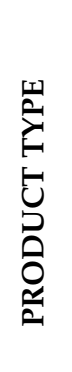 } & & Positive & Negative \\
\hline & Experience & $\begin{array}{l}\text { Condition 1: } \\
\text { - } \quad \text { Basic service } \\
\text { characteristics } \\
\text { - } \quad \text { OL eWOM + }\end{array}$ & $\begin{array}{l}\text { Condition 2: } \\
\text { - } \quad \text { Basic service } \\
\text { characteristics } \\
\text { - } \quad \text { OL eWOM - }\end{array}$ \\
\hline & Search & $\begin{array}{l}\text { Condition 3: } \\
\text { - } \quad \text { Basic product } \\
\text { characteristics } \\
\text { - } \quad \text { OL eWOM + }\end{array}$ & $\begin{array}{l}\text { Condition 4: } \\
\text { - } \quad \text { Basic product } \\
\text { characteristics } \\
\text { - } \quad \text { OL eWOM - }\end{array}$ \\
\hline 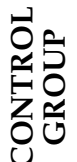 & Without OL eWOM & $\begin{array}{l}\text { Condition 5: } \\
\qquad \quad \text { Basic service/p }\end{array}$ & characteristics \\
\hline
\end{tabular}

\subsection{Pre-Test}

The pretest was carried out to guarantee that the stimuli and the study context were appropriate to measure the purchase behavior in the presence of product comments posted by an OL. The first thing we ensured was that the participant accessed both the information on the characteristics of the product and the comment posted by the OL.

The second issue was to make sure that the comments attributed to the OL were positive or negative. To ensure this, we selected 10 comments about smartphones and 10 about streaming posted freely by users on the amazon page and asked participants to rate the comments from 0 to 7 , being zero that they would never buy the product and 7 that they would buy it taking into account only the analyzed comments. As a result, we selected as a positive post the one with the highest average score and as a negative the one with the lowest score, both for Smartphone and Streaming. The scenarios shown to the participants are included in Appendix A.

The pretest was administered to 32 university students and after sending them the link to the online store via email, they received instructions to follow on the store. The result showed that only $42 \%$ of the participants clicked on the OL. Therefore, we decided to locate the post just on the right side of the image of the product or service, in this way we ensured visibility to the participants of the groups with treatment. Additionally, we added the measurement of the purchase time to differentiate it from the total browsing time and thus be able to establish the time that each participant devoted to making the decision. 
With these changes, we ran another pilot with 30 students from a different course and found that they all read the post and the total browsing time and time spent in the purchase process was significantly longer than the control group.

\subsection{Participants}

In total, 300 students from two public universities accessed and completed the entire procedure, 34 forms were discarded as incomplete or for being repeated users. In total, $51 \%$ were women; $76 \%$ of the participants were between 18 and 27 years old. A total of $79 \%$ stated that they read reviews before making purchases and $73 \%$ reported having previously made online purchases. Table 3 summarizes the socio-demographic characteristics of the sample studied.

Table 3. Respondents' demographic profile $(n=300)$.

\begin{tabular}{cccc}
\hline & & Frequency & Percentage \\
\hline Gender & Male & 144 & 47.7 \\
& Female & 154 & 51 \\
Age & Other & 4 & 1.3 \\
& $18-22$ & 135 & 45 \\
& $23-27$ & 93 & 31 \\
& $28-32$ & 35 & 11.7 \\
How long have you used the & $>33$ & 37 & 12.3 \\
Internet? & Less than 1 year & 5 & 1.7 \\
& 1 to 5 years & 29 & 9.7 \\
Have you shopped online before? & More than 5 & 266 & 88.7 \\
Read review /comments before & Yes & 220 & 73.3 \\
purchase? & No & 80 & 26.7 \\
& Yes & 237 & 79 \\
& No & 61 & 20.3 \\
\hline
\end{tabular}

\subsection{Experimental Stimuli}

All participants were exposed to the online technology store www.storetech.co designed specifically for this study. In it, two types of product catalogs were presented: smartphones and streaming services. Xiaomi, HTC, and Yotaphone were chosen as smartphone brands and Netflix, HBO, and Amazon Prime as streaming services.

Regarding the product comments or OL eWOM, the participants, according to the group to which they were randomly assigned, could read a comment. For example, in the case of the Smartphone "I bought this phone and was amazed at its fluidity, reliability, and ease of use. I will never buy another brand again, uncontrolled power is useless", as a positive comment attributed to OL.

For this part, Cristiano Ronaldo was chosen as OL. His election followed the criterion of greatest centrality [51]. By that time, he was the public figure with the largest number of followers on the social network Facebook, in addition to being widely known in the studied market since he played at that time in the Real Madrid with the most famous Colombian player (James). We wanted OL to be recognized by the people who participated in the study, regardless of being followers or not. In this way, we ensured that the participant recognized that the comment was posted by a celebrity and not by a stranger.

\subsection{Procedure}

The participants were contacted through the institutional mail of the universities. Through the mail, they were invited to participate and the access link to the online store was attached. When accessing, the participant had to register with an email account in the store. Subsequently, the system randomly assigned them to one of the five study groups and they received the following instruction: 
A leading e-commerce company wants to know your opinion about the shopping experience in its online technology store, therefore, we invite you to register and navigate through it, living the experience of buying in our store.

You will have access to three product options, compare them and choose the one you prefer, buy it or not as you wish, although you will not incur any monetary expense; However, as long as you make the best option, whether it is to buy or not and you justify it properly, you will be able to participate, at the end of the study, in the contest for a smartphone. Only people who complete the entire experience process and make the appropriate decision, depending on the context, will participate in the smartphone contest.

We appreciate your participation and guarantee the absolute anonymity and secrecy of your answers in strict compliance with the Law on statistical secrecy and protection of personal data. Once the information is anonymously recorded, the individual questionnaires are immediately destroyed.

By accepting terms and conditions, the participants were exposed to the shopping scenario according to the group to which they were assigned. Depending on the sender of the comments, the participant could be assigned to a group with an OL eWOM or to the control group. Depending on the valence of the message, the participants of the group with OL eWOM could be assigned to the positive comment (recommend the product/service) or negative (not recommended). Depending on the type of product, the participant was assigned to the catalog of smartphones or streaming services. In this phase, the participant, after analyzing the available information about the products, had to decide whether to buy or not.

In the last stage, the participants completed an online questionnaire on demographic information and online consumer habits (see Appendix B). The procedure ended by thanking the participant.

\subsection{Measures}

Independent variables. 1. eWOM sender: One group was shown OL eWOM, and the other was a control group (without eWOM). 2. Product type: Two types of products were included in the study (experiential versus search goods). We manipulated the type of product including one kind of good for each category. For experience goods, we used streaming video service subscriptions. For the search goods, we used three smartphone brands. 3. eWOM's valence: positive versus negative was manipulated in the betweengroups design. One group was shown a negative OL review about a product or service and the other group was shown a positive OL review.

Dependent variables. There were three dependent variables: product choice (PC), total time spent on the site (TTS), and shop time (ST). PC was evaluated based on the final selection that the participant made by clicking on the corresponding button for that purpose; it was a dichotomy variable (Buy/Not Buy). The two other variables, TTS and ST, were measured in seconds by the systems themselves. The former (TTS) started when the participant clicks on the instructions for the product evaluation and finished when he/she completes the process, and when the screen shows a "Thank you" message. The latter (ST) was measured, from the moment that the participant clicks on the registration button after completing the registration questionnaire, until they click on the "Buy" or "Not Buy" button.

\section{Results}

The results of the study are presented in this section, organized according to the hypotheses. In the first part, the descriptive analysis is presented, and then, the inferential analysis to test the hypotheses is discussed. 


\subsection{Descriptive Analysis}

The results, in terms of consumer behavior (buy, not buy) were analyzed according to the experimental group. With this information, we can describe the influence of treatments on purchasing behavior. These results are contrasted with inferential statistical tests in the following section of the document.

OL influence. Figure 2 shows the consumer's behavior (buy or not buy) according to the group that they were assigned: with OL recommendation or without it (Control Group). Nearly $50 \%$ of both groups selected 'buy', and the other decided 'not buy.' There was not much of a difference between the experimental group and the control group.

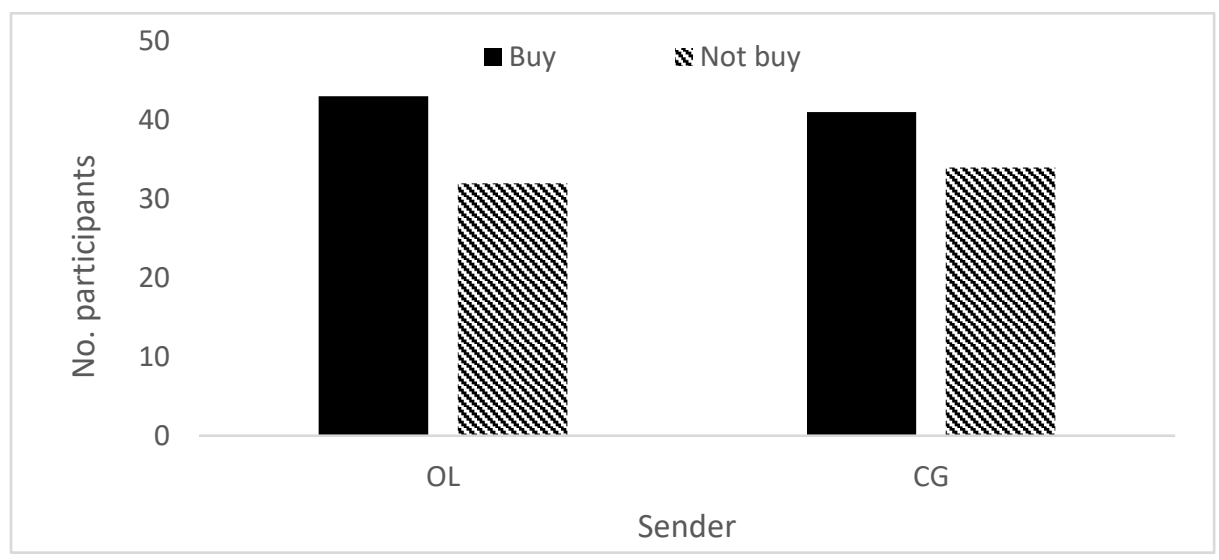

Figure 2. Consumer purchase behavior with or without OL eWOM.

Valence. In total, $68 \%$ of the OL eWOM positive valence group bought the product while only $23 \%$ of the negative valence group did (Figure 3).

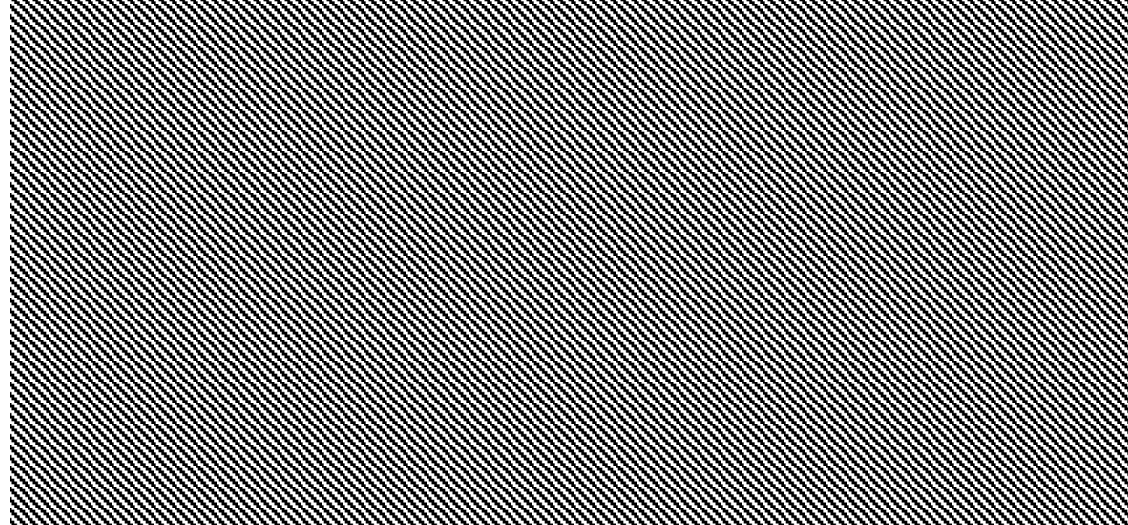

Figure 3. Consumer purchase behavior according to OL eWOM valence.

Product type. Figure 4 represents the consumer behavior according to the product type. A total of $77 \%$ of the experiential group made a purchase, and $23 \%$ did not. On the other hand, $73 \%$ of the search product group did not buy. 


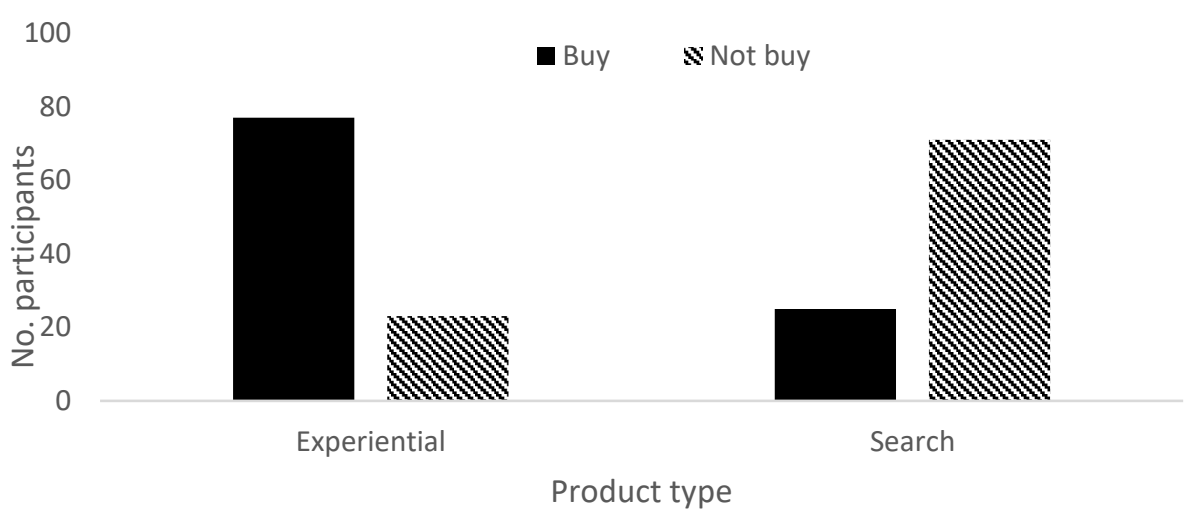

Figure 4. Consumer purchase behavior according to product type.

\subsection{Regression Coefficients and Hypotheses Testing}

To answer the research questions, we analyzed the data collected at the online store using SPSS Version 22. To test the three hypotheses, a Factor Analysis of Variance (FANOVA) with a Mixed Effect was conducted (Table 4) to assess the relationship between the dependent variable (purchase/no purchase (ST)) and the independent variables (OL eWOM and valence (positive/negative)) and product type (search/experiential goods). This analysis was the most appropriate due to the presence of non-normal data [52]. Preliminary tests performed on our sample showed the presence of non-normal data, particularly variable time. Therefore, FANOVA with a Mixed Effect, which is less severe when used for this type of bias, was conducted [53].

Table 4. Factor Analysis of Variance (FANOVA) for Mixed Effect and Hypotheses testing.

\begin{tabular}{ccccc}
\hline $\begin{array}{c}\text { Main Effect and } \\
\text { Interactions }\end{array}$ & df & $\mathbf{X}^{\mathbf{2}}$ & Hypothesis & Supported \\
\hline OL eWOM & 1 & 4.287 & $\mathrm{H}_{1}$ & No \\
Product type & 1 & $131.26^{*}$ & & \\
Valence & 2 & $122.08^{*}$ & & Yes \\
OL $x$ Valence & 2 & $14.245^{*}$ & $\mathrm{H}_{2}$ & Yes \\
OL x Product type & 2 & $22.063^{*}$ & $\mathrm{H}_{3}$ & \\
\hline${ }^{*} p<0.001$. & & &
\end{tabular}

The first hypothesis $\left(\mathrm{H}_{1}\right)$ holds that an OL eWOM about a product increases the probability of being bought, compared to the product without OL eWOM. The result of the analysis comparing the responses of the group with OL eWOM versus the control group $\left(\chi^{2}=4287.1\right)$ is not significant. Therefore, $\mathrm{H}_{1}$ was not supported. The comment or recommendation posted by an OL does not necessarily increase the probability that the product will be purchased, compared to one that has not been recommended by the OL.

With regard to sales, these results are consistent with those reported by Libai et al. [35] in terms of the limited ability to generate the value of an OL for the company. In the same way as Katona et al. [36], we found that OL exerted less influence than the recommendations generated by other consumers. Finally, the results are consistent with what was found by Danniswara et al. [37] regarding the limited influence of celebrity endorsement in purchasing decisions. However, the results are contrary to the literature, both at the traditional marketing level, and at the digital marketing one, on the role of OLs in mobilizing buyers. The literature has shown that OL favors the creation of favorable attitudes and intentions towards brands or products, but this research sheds light on the relativity of such influence to stimulate purchasing behavior.

On the other hand, when analyzing the main effect of the other two variables, OL eWOM valence $\left(\chi^{2}=122.08,1\right)$ and product type $\left(\chi^{2}=131.26,1\right)$, a significant relationship was found in the OL eWOM-valence and OL eWOM-product type interaction. Hypothesis $2\left(\mathrm{H}_{2}\right)$ postulates that the influence of OL eWOM is determined by the valence of the 
message. The results of comparing the groups with positive versus negative OL eWOM, in terms of the purchase decision $\left(\chi^{2}=14.245,2\right)$, supports this hypothesis. Figure 3 shows that the number of participants in the group with positive OL eWOM decided to buy (75\%) more than those who decided not to $(25 \%)$. On the other hand, regarding the participants in the group with negative OL eWOM, the percentage who decided not to buy $(60 \%)$ is higher than the one who decided to do so $(40 \%)$. Therefore, the interaction of OL eWOM and valence explains the decision to buy or not a product with OL eWOM.

The literature on the influence of eWOM posted by anonymous consumers on purchasing decisions has analyzed the role of the valence of the message [49]. Their results are not conclusive in terms of which has the greatest influence; even so, in global terms, we found that messages with negative valence tend to spread faster than positive ones. In terms of shaping consumption decisions, they seem to be more influential than positive messages. The results of our research show the role of valence when comments are posted by an OL. The results show that positive messages exert a greater influence on the decision to buy a product than not to buy it. Likewise, a negative message increases the probability of not buying the associated product. Therefore, in the end, when it comes to an OL eWOM, valence does matter and has a significant effect on the decision to buy or not.

Therefore, the outcomes of this research are consistent with the literature that affirms that positive messages have a greater influence on attitudes and purchase intentions. Furthermore, we provide empirical evidence of the ability to inhibit purchasing behaviors when deciding whether or not to purchase a product that has been commented on by an $\mathrm{OL}$ and the comment is of negative valence. Therefore, negative OL eWOM would not only spread faster, but could also deter the purchase.

In countries like the US, where comparative advertising is allowed, some companies often add the competing brand to their ads in a discrediting strategy. In these cases, if an OL were used to comment negatively on these brands, it would affect the sales of that brand. Therefore, negative messages are likely to be used as a social media marketing strategy as well.

Regarding hypothesis $3\left(\mathrm{H}_{3}\right)$, which states that an OL eWOM about an experience product has more influence on the purchase decision than an OL eWOM about a search good, the result of comparing the behavior of the participants of both groups $\left(\chi^{2}=22,063\right.$, 2) supports hypothesis 3 (See Table 5). Therefore, an OL eWOM on an experiential good is more likely to be bought than on a search-type good.

Table 5. OL eWOM, product type, and valence interaction results.

\begin{tabular}{cccccc}
\hline PRODUCT TYPE & LEADER & VALENCE & Difference (I-J) & gl & Sig. \\
\hline \multirow{3}{*}{ Search } & Opinion & Positive & -20.65 & 1 & 0.786 \\
& leader & Negative & -23.46 & 1 & 0.931 \\
\cline { 2 - 6 } & & Without & -34.24 & 1 & 0.672 \\
\hline \multirow{3}{*}{ Experiential } & Opinion & Positive & 24.567 & 1 & $0.000^{*}$ \\
& leader & Negative & 9.86 & 1 & 0.340 \\
\cline { 2 - 6 } & & Without & 0.93 & 1 & 0.235 \\
\hline
\end{tabular}

* Groups are significantly different $(p<0.00)$.

The attributes of a search good can be evaluated by the customer before purchasing or using it, while experience good can only be evaluated after its purchase or consumption. Therefore, the level of risk assumed by the consumer in purchasing decisions is differential according to the type of product. To try to reduce risk, consumers tend to read reviews from other consumers. In this research, we analyze the influence of an OL eWOM on an experience good (streaming services) versus a search good (smartphones).

These outcomes provide evidence of the greater susceptibility on the part of the consumer when making decisions about experience goods versus search goods. They are consistent with Tsao et al. [10], regarding the greater influence of eWOM in decision-making 
on experience goods than on search goods. However, it does not support the conclusions of Kim et al. [47] regarding the greater susceptibility of search goods than those of experience.

\section{Discussion}

The role of OL has been changing with the massification of social networks. While according to Katz and Lazerfeld's [2] approach, in the traditional model an OL plays a key role in making decisions, regarding new products or services, among his/her followers; however, in social networks such as Facebook or Twitter, although they have more followers, it seems that their influence becomes more limited.

De Veirman et al. [54] demonstrated that the number of followers is important for an OL to be considered more popular. However, it is not enough for changing brand attitudes. Our research is consequent with these results, the OL has millions of followers but his/her capacity to change purchase behaviors is limited. Therefore, the strategy of using an OL to promote products requires a correct segmentation. The simple use of an OL does not guarantee an increase in sales-it is necessary to analyze the type of product and the valence of the message.

Furthermore, social influence is a complex phenomenon that combines the characteristics of an OL and his/her followers, and the context in which the relationship is established [55]. In this research, we analyze, in a controlled context, the effect of a product/service comment issued by an OL. The results show that the influence of an OL in terms of final purchase decisions is limited to the type of product and the valence of the message.

The nature of the product is a characteristic that has been shown to have a differential influence on the purchase decision process. Experience goods tend to imply a higher risk nature due to the social consequences of their use or consumption, while search goods have more immediate consequences [10] depending on whether they adequately satisfy the operational need for which they were designed. Therefore, the susceptibility to be influenced by an OL on the decision to buy or not a product or service. The recommendation made by an OL to buy an experience good has a greater influence on consumer behavior than if the recommendation is about a search good.

The valence of the message in the context of the social influence of an OL regains relevance when making consumption decisions. The eWOM literature has shown that a negative message spreads more easily than a positive valence one [56]. However, when the message is sent by an OL, the effect in terms of influencing purchasing behavior is different. If the message is negative it is less decisive than if it is positive. Therefore, we could affirm with the evidence collected in this study and the existing literature that a negative valence message is more prone to spread quicker than a positive one, but when the message is posted by an OL, its effect on consumer decisions is different. An OL eWOM with positive valence has a greater effect on the purchase decision than a negative message on dissuading it.

Therefore, depending on the objective of the communication strategy, if what is intended is to create virality, a negative message posted by an OL has a greater reach than a positive one. However, if what is intended is to increase sales, product recommendations are appropriate, although they have less diffusion [42]. Therefore, the valence of the messages sent by an OL has a differential effect on the purchase decisions or not of its followers. A positive message (product recommendation) has a greater influence on the decision to buy than a negative message on the decision not to buy.

Doh and Hwang [43] showed that negative messages not only spread more quickly but had a greater influence on consumer decisions. However, the outcome of this investigation allows us to conclude that when the message is sent by an OL, the influence is different: a positive message is more decisive for the consumer. This can be explained by the fact that followers want to hear positive messages from their opinion leaders, and when they criticize something or someone, they are less persuasive. However, the results of this research also shed light on negative valence OL eWOMs, which also exert a deterrent 
influence on buying. Consequently, its use in comparative advertising strategies can favor the positioning of the brand in the market compared to those of the competition.

Finally, the influence of the OL is conditioned on the type of product; buying an experiential good has more risk, which makes the OL eWOM more significant [10]. As the consumer cannot interact with the product before purchasing it and since satisfaction is a function of the final experience, after paying for it, the consumer can try to reduce the decision risk by following a recognized person or the advice of other consumers [33]. Moreover, if the type of product is more in line with the OL personality and style, the message is more effective by increasing the likelihood of buying the product or service.

Schouten et al. [57] found that the consumer believes in online influencers but their influence was conditioned to product-endorsed fit. Therefore, not all OLs are effective for all types of products. The greater the similarity between OL and the product that it promotes concerning its style and type of activity, the greater efficiency in the commercial communication generated.

For that reason, in the digital era, an OL can be anyone who has thousands of followers [5]. However, his/her influence is not only limited to spreading information, but it is determined by the kind of good that he/she is promoting and the valence of the message that he/she is sharing. The practitioner has to do an appropriate segmentation of the market if they want to use this kind of strategy to promote their products.

\section{Conclusions}

OL is a person with the ability to influence the beliefs, attitudes, and behaviors of his/her social group. According to Katz and Lazarsfeld [2], in the traditional context of marketing, OL plays a central role in the commercial communication strategy of a firm, by transmitting communications from the mass media to its group of followers, making the messages much more credible. However, with the massification of online social networks, from being transmitters of communication they have become content generators. This phenomenon is known as eWOM, which is not exclusive to OLs but can be generated by any user of a social network, with the difference that OLs have access to a greater number of followers and therefore greater communication capacity. Although, what scope have these communications posted by an OL (OL eWOM) about the purchase decisions of his/her followers?

This research analyzed, through an experimental design in an online store, the influence that a product comment posted by an OL (OL eWOM) on their social network account has on the decision to buy or not the related product. Additionally, the role of the valence of OL eWOMs and the type of product was analyzed to establish the scope of this type of communication in the consumer's purchase decision.

The results allow us to conclude that when comparing the influence of an OL eWOM against a control group, the influence of OL eWOM is limited, without exceeding the random effect. However, when the valence of $\mathrm{OL}$ eWOM and the nature of the product were analyzed, a significantly higher influence was found for OL eWOM to the control group. Specifically, this research provides evidence that an OL eWOM with a positive valence has a greater influence in promoting the purchase of the product than the effect that an OL eWOM with a negative valence has in deterring the purchase. Likewise, the results show that when the OL eWOM corresponds to an experience good and the valence is positive, it has a greater influence than when it is a search good. Similarly, a negative OL eWOM deters the purchase of an experience good more than the effect than a search good.

This research provides evidence on the online communications phenomenon known as eWOM and its influence on consumer decisions. The main contribution focuses on demonstrating the relative influence of eWOM when it is posted by an OL from their social network account. Therefore, without being a brand endorsement (or celebrity endorsement) strategy, it appeals to the spontaneity of the eWOM, but with the scope in terms of the number of followers or users that it can impact. 
eWOM literature has shown that the valence of the message and the type of product are relevant when studying their influence on consumer decisions. This research corroborated that these variables exert a significant influence to guide the purchase of a good or to deter it. However, this research sheds new light on the effect of negative valence OL eWOMs, which have generated much controversy in the eWOM literature. This research reports that although they have a lesser effect than positive messages, they exert an influence on the deterrence of the purchase, which can be used in comparative advertising strategies.

Likewise, the outcomes of this research made it possible to show that the purchase of experiential goods is more likely to be influenced by OL eWOM. This is explained by the attribute of intangibility that carries greater risks for the consumer, which makes it more likely to follow the recommendations of public figures before making such decisions [3]. The case of the good that we have used (streaming services), is a service that the consumer only knows if it is what he/she expected or not when he/she tried it. The fact of including an OL eWOM in the description favors the assumption of risks. Therefore, it is highly recommended to include comments from other consumers or a widely recognized character.

Kim et al. [47] found that eWOM has a greater influence on purchase intentions when it comes to search goods than experience goods. However, the results of this study do not support these conclusions. Our results showed that participants in the experience goods groups and the search goods groups reacted differently to the positive and negative OL eWOMs. In this case, the influence of OL eWOM (positive/negative) was greater both to buy and to discourage buying an experience good than a search one. This may happen because buying online in itself involves risks for the consumer, but, when acquiring a search good, such as a smartphone, it is possible to leave the purchase or return it later, in case of dissatisfaction, rather than in the case of experiential good. Therefore, although online shopping involves risks for the consumer, regardless of the type of product, the purchase of an experience good is riskier than a search one [10].

\subsection{Research Implications}

The study of social influence through social networks is a topic that has aroused great interest both at an applied and theoretical level since consumers spend a large amount of time on social networks, reading news, communicating with family and friends, or following artists, athletes, and famous people that in previous times it was only possible to watch on television [4]. This new form of communication, which is different from the previous one bilaterally, has opened a universe of possibilities for interaction and has therefore become an object of study both in the social sciences and in disciplines such as marketing [26].

This research has used an experiment in an online store designed for this, to simulate a shopping scenario, where thanks to technological tools we were able to insert product comments (eWOM) in the account of a social network of an OL. Using this methodology, we studied what type of interaction the participants had not only with the store itself but with the OL eWOM and in a controlled way, we studied how much influence these communications had on the purchasing decisions of the participants.

The results have implications at a methodological and theoretical level. On the one hand, it allows us to delve into the use of online experiments to carry out basic research, simulating real purchase scenarios that companies are empirically carrying out with their digital marketing strategies at the application level [18]. On the other hand, it allows us to measure in a controlled way how much a strategy with the use of OL can work and in what contexts. The existing literature on social influence on social networks, in the form of user-generated communications (eWOM), has grown dramatically in the last 10 years [49]. For its part, the study of the use of public figures in the design of advertising strategies is a common practice among companies [14]. However, the study on how much the communications posted by OL in the form of product comments (OL eWOM) influences on purchase decisions was pending. 
This research fills that gap and makes it possible to quantify the impact of this type of communication. The results shed light on the limitations and scope of this type of strategy. In the specific case, we find that OL eWOMs have an influence contingent on the type of product and the direction of the message it communicates. Therefore, not all communications posted by an OL on his/her social network account has the same effect on purchasing behavior. Therefore, followers are not passive subjects of their opinion leaders' communications, but rather choose information based on the risks they can and want to assume in their online purchasing decisions.

\subsection{Managerial Implications}

It is widely known that companies spend millions of dollars annually hiring celebrity image services to promote their products [19]. The literature so far has studied the role of these communications and their ability to generate movement in social networks (virality) [26]. In some cases, it has been studied how much they influence the purchase intention, but what has not been systematically measured both influences the purchase decision, the ultimate reason why companies invest this money.

This research addressed this matter and the results allow us to conclude in which contexts it is more appropriate to use OL communications and under what conditions according to the strategy that the company decides. OL eWOM has a greater influence on experience goods which are characterized by not being able to know the result of their performance until they have been experienced and therefore paid. Consequently, they pose greater risks of making a mistake by the customer in their purchase decision and consequently the role of OL eWOM regains relevance [58].

For their part, the communication strategies that companies implement, in the vast majority of cases, are aimed at highlighting the advantages of their brand. However, combining the use of an OL along with favorable product recommendations can be much more credible and effective in boosting sales. On the other hand, in countries such as the USA where comparative advertising is allowed and in Europe (although with certain restrictions) [59], using negative OL eWOM to competitor brands can have not only the benefits of becoming more easily viral but like the outcomes of this research, they can also inhibit the purchase of the related product.

Therefore, having a clear idea of who the company's target market is and what its communication strategy is, the use of OL eWOM is a feasible and cheaper way, and with the appropriate segmentation, favorable results can be obtained to increase sales and product visibility on social media.

As an example, Netflix recently used a comment that a user posted on their social network about this brand of streaming service [60]. The comment was more negative than positive, but it gained brand visibility on social media and increased traffic to the company's page and subsequently the volume of subscriptions. These communications on social networks are the challenge of companies, which more than fear them, could use them as a vehicle to make the brand visible and increase prospects.

\subsection{Limitations and Future Research}

This research had some limitations that constitute future lines of research on the scope of the influence of an OL in consumer decisions in e-commerce. First, the sample selected was extracted from a population of university students, which is conducive to the type of products and services analyzed, which can limit the scope in terms of generalization of the results. Therefore, including other segments of the population would deepen the scope of this type of communication strategy.

Moreover, repeating the procedure with another OL and with products or services of another nature would make it possible to elucidate whether the trend of the results is maintained or can, an OL of another nature, have a greater influence on consumer decisions. For example, opinion leaders from areas other than football, such as politics, science, or 
television. Additionally, more standardized products or, on the contrary, luxury items or specialized products could be studied.

Likewise, studying the influence of OLs according to their characteristics such as profession, gender, type of social network that they frequent, etc., would be of interest to delve into the role of OLs in the digital age.

Finally, it is necessary to compare the influence of the recommendations when they are sent by OLs regarding the influence against when they are recommended by other anonymous reviewers.

Author Contributions: Conceptualization, S.T. and J.G.-M.; methodology, S.T.; writing—original draft preparation, S.T., writing—review and editing, S.T. and J.G.-M.; All authors have read and agreed to the published version of the manuscript.

Funding: This research received no external funding.

Institutional Review Board Statement: The study was conducted according to the guidelines of the Declaration of Helsinki, and approved by the Institutional Review Board (or Ethics Committee) of Complutense University of Madrid (Ethics code, 14 January 2017).

Informed Consent Statement: Informed consent was obtained from all subjects involved in the study.

Data Availability Statement: Not applicable.

Conflicts of Interest: The authors declare no conflict of interest.

\section{Appendix A}
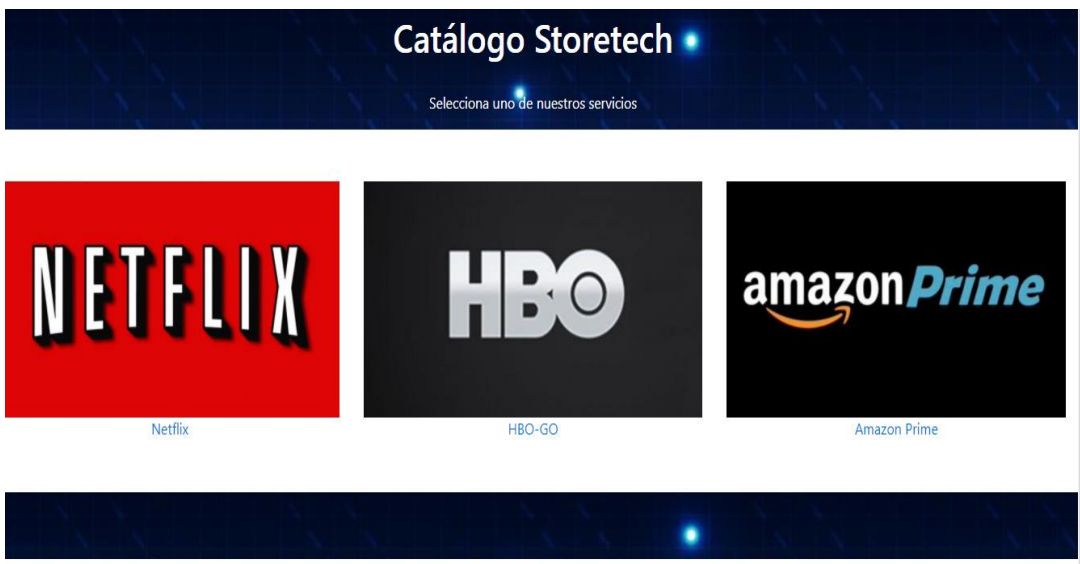

Figure A1. Experimental stimulus: Services brands.

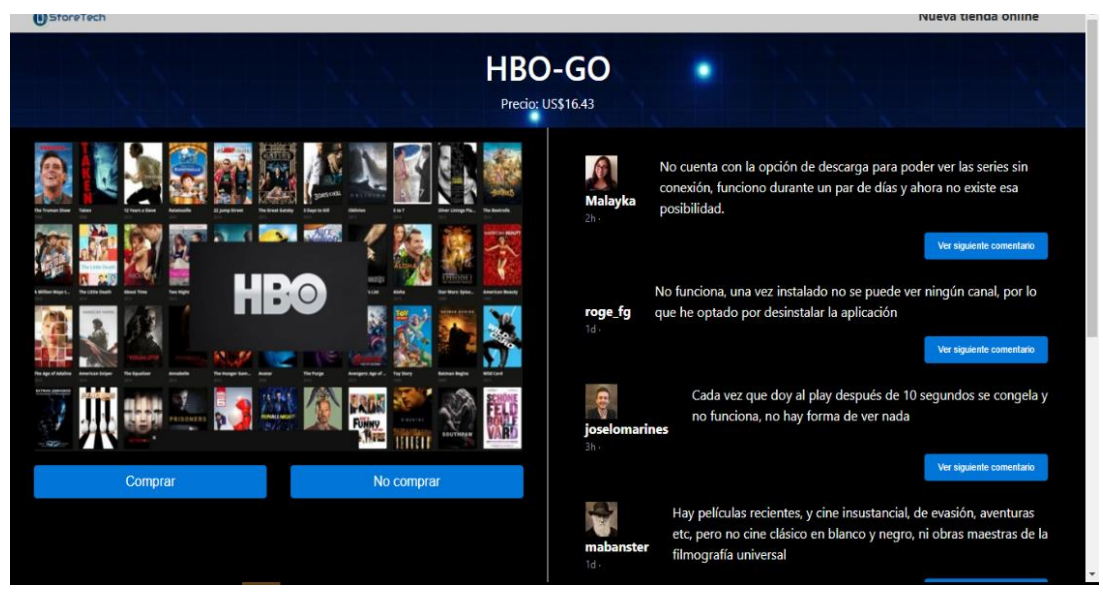

Figure A2. Consumer reviews example. 


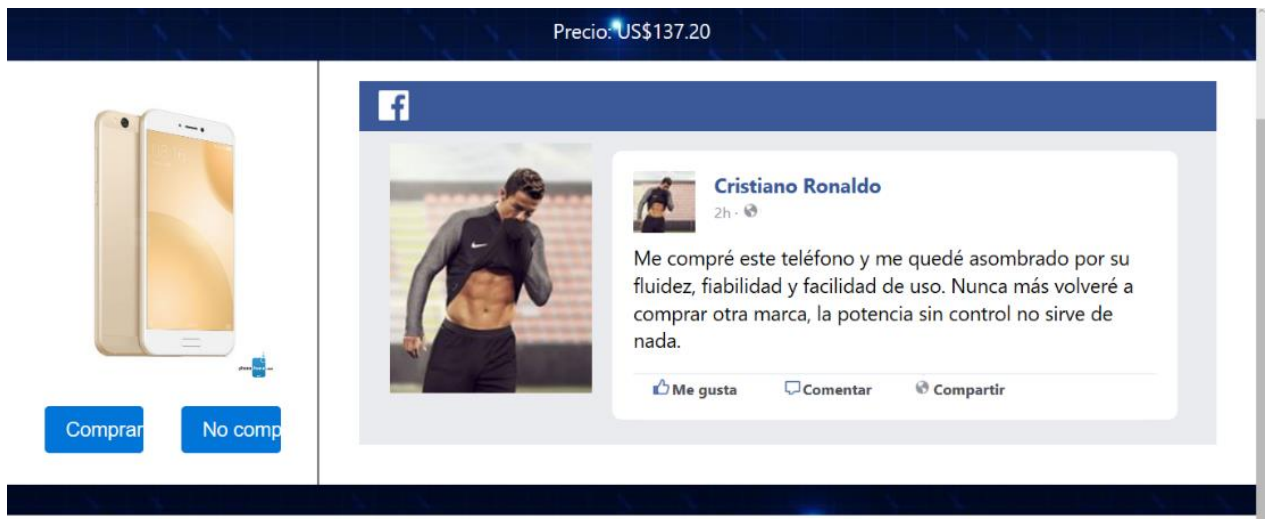

Figure A3. Opinion Leader's recommendation example.

\section{Appendix B}

Registration information form

Complete the following information to register for the online store.

Gender: Male/Female

Age: 18-22/23-27/28-32/33+

How long have you been using the Internet? Never/Less than 1 year/1-5 years/More than 5 years

Did you shop online in the last month? Yes/no

In the last month, how many times did you shop online? 1-3/4-6/7-9/More than 10 times.

What type of goods have you bought online? Products/Services.

Do you check the opinions of other consumers on the web before buying? Yes/No

Do you usually comment on the products or services you have purchased online? Yes/No.

\section{References}

1. Bao, T.; Chang, T.-L.S. Finding disseminators via electronic word of mouth message for effective marketing communications. Decis. Support Syst. 2014, 67, 21-29. [CrossRef]

2. Katz, E.; Lazarsfeld, P. Personal Influence: The Part Played by People in the Flow of Mass Communications; Transaction Publishers: Piscataway, NJ, USA, 2009.

3. Iyengar, R.; Van den Bulte, C.; Valente, T.W. Opinion Leadership and Social Contagion in New Product Diffusion. Mark. Sci. 2011, 30, 195-212. [CrossRef]

4. Global Web Index. Social media marketing trends in 2020. 2020. Available online: https:/ /www.globalwebindex.com/reports/ social (accessed on 30 October 2020).

5. Weeks, B.E.; Ardèvol-Abreu, A.; Gil De Zúñiga, H. Online influence? Social media use, opinion leadership, and political persuasion. Int. J. Qual. Heal. Care 2015, 29, edv050. [CrossRef]

6. Sari, D.M.F.P.; Yulianti, N.M.D.R. Celebrity endorsement, electronic word of mouth and trust brand on buying habits. Int. J. Soc. Sci. Humanit. 2019, 3, 82-90. [CrossRef]

7. Statista. From Most Popular Facebook Fan Pages as of September 2019, Based on Number of Fans (in Millions) Website. 2019. Available online: https:/ /www.statista.com/statistics/269304/international-brands-on-facebook-by-number-of-fans/ (accessed on 12 February 2019).

8. Katz, E. The two-step flow of communication: An up-to-date report on an hypothesis. Public Opin. Q. 1957, 21, 61-78. [CrossRef]

9. Roy, G.; Datta, B.; Basu, R. Effect of eWOM valence on online retail sales. Glob. Bus. Rev. 2017, 18, 198-209. [CrossRef]

10. Tsao, W.-C.; Hsieh, M.-T. eWOM persuasiveness: Do eWOM platforms and product type matter? Electron. Commer. Res. 2015, 15, 509-541. [CrossRef]

11. Hussain, S.; Huang, K.; Ilyas, Z.; Niu, B. Exploring the novel input attributes affecting eWOM. Front. Psychol. 2020, 11. [CrossRef]

12. Gnambs, T.; Batinic, B. The roots of interpersonal influence: A mediated moderation model for knowledge and traits as predictors of opinion leadership. Appl. Psychol. 2012, 62, 597-618. [CrossRef]

13. Cheung, C.M.K.; Thadani, D.R. The impact of electronic word-of-mouth communication: A literature analysis and integrative model. Decis. Support Syst. 2012, 54, 461-470. [CrossRef]

14. Schimmelpfennig, C.; Hunt, J.B. Fifty years of celebrity endorser research: Support for a comprehensive celebrity endorsement strategy framework. Psychol. Mark. 2019, 37, 488-505. [CrossRef] 
15. Flynn, L.R.; Goldsmith, R.E.; Eastman, J.K. Opinion leaders and opinion seekers: Two new measurement scales. J. Acad. Mark. Sci. 1996, 24, 137-147. [CrossRef]

16. Hung, K.H. Why celebrity sells: A dual entertainment path model of brand endorsement. J. Advert. 2014, 43, 155-166. [CrossRef]

17. Jin, S.V.; Ryu, E. Celebrity fashion brand endorsement in Facebook viral marketing and social commerce: Interactive effects of social identification, materialism, fashion involvement, and opinion leadership. J. Fash. Mark. Manag. Int. J. 2019, 23, 104-123. [CrossRef]

18. Ki, C.-W.; Cuevas, L.M.; Chong, S.M.; Lim, H. Influencer marketing: Social media influencers as human brands attaching to followers and yielding positive marketing results by fulfilling needs. J. Retail. Consum. Serv. 2020, 55, 102133. [CrossRef]

19. Shan, Y.; Chen, K.-J.; Lin, J.-S. When social media influencers endorse brands: The effects of self-influencer congruence, parasocial identification, and perceived endorser motive. Int. J. Advert. 2020, 39, 590-610. [CrossRef]

20. Knoll, J.; Matthes, J. The effectiveness of celebrity endorsements: A meta-analysis. J. Acad. Mark. Sci. 2017, 45, 55-75. [CrossRef]

21. Hwang, K.; Zhang, Q. Influence of parasocial relationship between digital celebrities and their followers on followers' purchase and electronic word-of-mouth intentions, and persuasion knowledge. Comput. Hum. Behav. 2018, 87, 155-173. [CrossRef]

22. Weimann, G. The Influentials: Back to the concept of opinion leaders? Public Opin. Q. 1991, 55, 267-279. [CrossRef]

23. Loeper, A.; Steiner, J.; Stewart, C. Influential opinion leaders. Econ. J. 2014, 124, 1147-1167. [CrossRef]

24. Hinz, O.; Skiera, B.; Barrot, C.; Becker, J.U. Seeding strategies for viral marketing: An empirical comparison. J. Mark. 2011, 75, 55-71. [CrossRef]

25. Trepte, S.; Scherer, H. Opinion leaders-Do they know more than others about their area of interest? Communications 2010, 35, 119-140. [CrossRef]

26. Wang, Z.; Liu, H.; Liu, W.; Wang, S. Understanding the power of opinion leaders' influence on the diffusion process of popular mobile games: Travel frog on Sina Weibo. Comput. Hum. Behav. 2020, 109, 106354. [CrossRef]

27. Turcotte, J.; York, C.; Irving, J.; Scholl, R.M.; Pingree, R.J. News recommendations from social media opinion leaders: Effects on media trust and information seeking. J. Comput. Commun. 2015, 20, 520-535. [CrossRef]

28. Lin, H.-C.; Bruning, P.F.; Swarna, H. Using online opinion leaders to promote the hedonic and utilitarian value of products and services. Bus. Horiz. 2018, 61, 431-442. [CrossRef]

29. López, M.; Sicilia, M. Determinants of E-WOM influence: The role of consumers' internet experience. J. Theor. Appl. Electron. Commer. Res. 2014, 9, 7-8. [CrossRef]

30. Luqiu, L.R.; Schmierbach, M.; Ng, Y.-L. Willingness to follow opinion leaders: A case study of Chinese Weibo. Comput. Hum. Behav. 2019, 101, 42-50. [CrossRef]

31. Sahelices-Pinto, C.; Lanero, A.; Vázquez-Burguete, J.L.; Rodríguez, P.G. Ewom and 2.0 opinion leaders in the food context: A study with a sample of spanish food-related weblogs. J. Food Prod. Mark. 2017, 24, 328-347. [CrossRef]

32. Huhn, R.; Ferreira, J.B.; De Freitas, A.S.; Leão, F. The effects of social media opinion leaders' recommendations on followers' intention to buy. Rev. Bus. Manag. 2018, 20, 57-73. [CrossRef]

33. Shan, Y. How credible are online product reviews? The effects of self-generated and system-generated cues on source credibility evaluation. Comput. Hum. Behav. 2016, 55, 633-641. [CrossRef]

34. Moldovan, S.; Muller, E.; Richter, Y.; Yom-Tov, E. Opinion leadership in small groups. Int. J. Res. Mark. 2017, 34, 536-552. [CrossRef]

35. Libai, B.; Muller, E.; Peres, R. Decomposing the value of word-of-mouth seeding programs: Acceleration versus expansion. J. Mark. Res. 2013, 50, 161-176. [CrossRef]

36. Katona, Z.; Zubcsek, P.P.; Sarvary, M. Network effects and personal influences: The diffusion of an online social network. J. Mark. Res. 2011, 48, 425-443. [CrossRef]

37. Danniswara, R.; Sandhyaduhita, P.; Munajat, Q. The impact of EWOM referral, celebrity endorsement, and information quality on purchase decision: A case of Instagram. Inf. Resour. Manag. J. 2017, 30, 23-43. [CrossRef]

38. Wu, P.F. In search of negativity bias: An empirical study of perceived helpfulness of online reviews. Psychol. Mark. 2013, 30, 971-984. [CrossRef]

39. Jin, S.-A.A.; Phua, J. Following celebrities' tweets about brands: The impact of twitter-based electronic word-of-mouth on consumers' source credibility perception, buying intention, and social identification with celebrities. J. Advert. 2014, 43, 181-195. [CrossRef]

40. Aleti, T.; Pallant, J.I.; Tuan, A.; van Laer, T. Tweeting with the stars: Automated text analysis of the effect of celebrity social media communications on consumer word of mouth. J. Interact. Mark. 2019, 48, 17-32. [CrossRef]

41. Hornik, J.; Satchi, R.S.; Cesareo, L.; Pastore, A. Information dissemination via electronic word-of-mouth: Good news travels fast, bad news travels faster! Comput. Hum. Behav. 2015, 45, 273-280. [CrossRef]

42. Kim, S.J.; Wang, R.J.-H.; Maslowska, E.; Malthouse, E.C. "Understanding a fury in your words": The effects of posting and viewing electronic negative word-of-mouth on purchase behaviors. Comput. Hum. Behav. 2016, 54, 511-521. [CrossRef]

43. Doh, S.-J.; Hwang, J.-S. How Consumers evaluate eWOM (Electronic Word-of-Mouth) messages. CyberPsychology Behav. 2009, 12, 193-197. [CrossRef]

44. Lee, J.; Park, D.-H.; Han, I. The effect of negative online consumer reviews on product attitude: An information processing view. Electron. Commer. Res. Appl. 2008, 7, 341-352. [CrossRef] 
45. Zhang, J.Q.; Craciun, G.; Shin, D. When does electronic word-of-mouth matter? A study of consumer product reviews. J. Bus. Res. 2010, 63, 1336-1341. [CrossRef]

46. Armstrong, G.; Kotler, P. Marketing: An Introduction, 14th ed.; Pearson: New York, NY, USA, 2019.

47. Kim, J.; Lee, J.; Ragas, M. Exploring eWOM in online consumer reviews: Experience versus search goods-The web journal of mass communication research. Web J. Mass Commun. Res. 2011, 32, 1-16.

48. Ahmad, S.N.; Laroche, M. Analyzing electronic word of mouth: A social commerce construct. Int. J. Inf. Manag. 2017, 37, 202-213. [CrossRef]

49. Rosario, A.B.; de Valck, K.; Sotgiu, F. Conceptualizing the electronic word-of-mouth process: What we know and need to know about eWOM creation, exposure, and evaluation. J. Acad. Mark. Sci. 2020, 48, 422-448. [CrossRef]

50. Racherla, P.; Friske, W. Perceived 'usefulness' of online consumer reviews: An exploratory investigation across three services categories. Electron. Commer. Res. Appl. 2012, 11, 548-559. [CrossRef]

51. Zhao, Y.; Kou, G.; Peng, Y.; Chen, Y. Understanding influence power of opinion leaders in e-commerce networks: An opinion dynamics theory perspective. Inf. Sci. 2018, 426, 131-147. [CrossRef]

52. Dobson, A.J.; Barnett, A.G. An Introduction to Generalized Linear Models, 4th ed.; CRC Press: London, UK, 2018.

53. Abramovich, F.; Angelini, C. Testing in mixed-effects FANOVA models. J. Stat. Plan. Inference 2006, 136, 4326-4348. [CrossRef]

54. De Veirman, M.; Cauberghe, V.; Hudders, L. Marketing through Instagram influencers: The impact of the number of followers and product divergence on brand attitude. Int. J. Advert. 2017, 36, 798-828. [CrossRef]

55. Casaló, L.V.; Flavian, C.; Ibáñez-Sánchez, S. Influencers on Instagram: Antecedents and consequences of opinion leadership. J. Bus. Res. 2020, 117, 510-519. [CrossRef]

56. Dalman, M.D.; Chatterjee, S.; Min, J. Negative word of mouth for a failed innovation from higher/lower equity brands: Moderating roles of opinion leadership and consumer testimonials. J. Bus. Res. 2020, 115, 1-13. [CrossRef]

57. Schouten, A.P.; Janssen, L.; Verspaget, M. Celebrity vs. Influencer endorsements in advertising: The role of identification, credibility, and Product-Endorser fit. Int. J. Advert. 2020, 39, 258-281. [CrossRef]

58. Cho, V.; Chan, A.; Cho, V. A study on the influence of eWOM using content analysis: How do comments on value for money, product sophistication and experiential feeling affect our choices? Enterp. Inf. Syst. 2016, 11, 927-948. [CrossRef]

59. Bambauer-Sachse, S.; Heinzle, P. Comparative advertising for goods versus services: Effects of different types of product attributes through consumer reactance and activation on consumer response. J. Retail. Consum. Serv. 2018, 44, 82-90. [CrossRef]

60. Diaz, J. Netflix sorprende con campañas y ahora tweet murciano-ProgPublciidad, Programa Public. 2019. Available online: https:/ / www.programapublicidad.com/netflix-lanza-campana-madrid-tweet-murciano/ (accessed on 23 October 2020). 